www.scielo.br/rbg

\title{
IDENTIFICAÇÃO DE REFLEXÕES MÚLTIPLAS, UTILIZANDO OS PARÂMETROS DAS FRENTES DE ONDA PIN E NORMAL
}

\author{
Francisco José Mota de Souza \\ Orientador: Dr. João Carlos Ribeiro Cruz (UFPA) \\ 69 p. - Dissertação (Mestrado) - Defesa 19.08.2005
}

\begin{abstract}
RESUMO. As reflexões múltiplas presentes nos sismogramas ocultam informações importantes sobre os refletores em subsuperfície e, podem até tornar completamente invisíveis as reflexões primárias, como no caso dos sismogramas marinhos, que muitas das vezes, exibem uma aparência anelar com fortes superposições das reflexões múltiplas, sobre as reflexões primárias. Problema este que tem sido alvo de importantes pesquisas, com 0 intuito de identificar, atenuar e/ou eliminá-las, através de vários métodos populares. 0 objetivo principal deste trabalho é a identificação das reflexões múltiplas. Com essa finalidade foi gerada, por modelamento direto, uma seção sísmica, com afastamento nulo (AN), contendo reflexões primárias e múltiplas simétricas de primeira ordem. Posteriormente, foi aplicada a migração cinemática do tipo Kirchhoff para obter 0 modelo em profundidade, apresentando uma boa recuperação dos refletores, bem como a presença de um refletor fictício, quando comparado com a seção anteriormente especificada. Foi obtida uma seção sísmica AN, do modelo migrado, na qual não é observado o segundo refletor, devido à ausência de contraste de impedância, entre a segunda e terceira camada, sendo este o primeiro indício de que o refletor fictício deste modelo é uma múltipla. Outro indício sobre a existência da múltipla foi a simetria encontrada entre as curvaturas do primeiro e terceiro refletor. Finalmente, foram calculados os parâmetros das frentes de ondas Hipotéticas Ponto de Incidência Normal (PIN) e Normal (N), bem como a velocidade Normal Moveout (NMO), tanto para os eventos de reflexões primárias como os eventos de reflexões múltiplas, para o modelo direto e para o modelo migrado. Em seguida, foram realizadas as comparações destes parâmetros, o que permitiu confirmar a veracidade dos indícios anteriores para a identificação das reflexões múltiplas.
\end{abstract}

ABSTRACT. The multiple reflections present in seismograms hide important information of reflectors in subsurface, sometimes turning primary reflections invisible. This is the case of marine seismograms, in which sometimes they present a ring-like appearance, with strong superposition of multiple reflections, together with primary reflections. This problem has been the subject of important researches, whose principal objective is the identification, attenuation and elimination of multiples, using in this respect some widespread methods. The objective of this work is the identification of multiple reflections. With this purpose, we have forward modeled zero-offset (ZO) seismic sections containing primary reflections, together with first-order multiple reflections. Later on, we have performed a kinematic Kirchhoff depth migration in order to obtain a simulated geological model in depth, with true and fictitious reflectors at the same time. From this depth migrated section, we have modeled a ZO section, in which the fictitious reflector is not recorded, due to the impedance contrast in the second and third layers of the model. This is the first clue that the referred fictitious reflector is, in fact, the result of imaging a multiple reflection. Another clue for this assertion is the semblance of the curvatures of the first and third reflectors. Finally, the wavefront parameters of two hypothetical waves Normal Incidence Point (NIP) and Normal (N) were computed, as well as the NMO velocity for the primary and multiple events, in the forward and migrated models. We have finally compared these parameters in order to verify the later clues with respect to the identification of multiple reflections. 